\title{
PEMBANGUNAN PERANGKAT LUNAK BUSINESS INTELLIGENCE DI DINAS PERHUBUNGAN KABUPATEN BANDUNG BARAT
}

\author{
Rd. Harry Martiadi \\ Fakultas MIPA, Program Studi Informatika \\ Universitas Jenderal Achmad Yani \\ Email: harry_kentuy@yahoo.co.id \\ Tacbir Hendro Pudjiantoro \\ Fakultas MIPA, Program Studi Informatika \\ Universitas Jenderal Achmad Yani \\ Faiza Renaldi \\ Fakultas MIPA, Program Studi Informatika \\ Universitas Jenderal Achmad Yani \\ Email: faiza.renaldi@unjani.ac.id
}

\begin{abstract}
ABSTRAK
PKB (Pengujian Kendaraan Bermotor) merupakan UPTD (Unit Pelaksana Teknis Daerah) yang menguji kendaraan bermotor yang berdasarkan kepada peraturan mentri 133 tahun 2015. Bila dilihat dari Tugas Pokok dan Fungsi (Tupoksi) jabatannya, para penguji kendaraan bermotor adalah penegak kelancaran dan kesesuaian kendaraan yang harus disesuaikan dengan keperuntukannya. Dengan menguji seluruh kendaraan angkutan barang dan angkutan orang UPTD Pengujian Kendaraan Bermotor selalu mengayomi masyarakat untuk menjaga dan merawat kendaraan bermotor supaya tetap berfungsi maksimal untuk digunakan sehari-hari, UPTD PKB (Pengujian Kendaraan Bermotor) juga merupakan salah satu komponen penting dalam upaya peningkatan perekonomian dan keselamatan masyarakat, juga sebagai indikator kemajuan yang telah dicapai oleh suatu daerah. Kepala UPTD memerlukan informasi dan analisis tentang pengujian kendaraan bermotor yang sudah dilakukan. Penelitian ini bertujuan membangun sistem informasi pengujian kendaraan bermotor menggunakan Business Intllegence untuk memudahkan pegawai dan KA UPTD (Kepala Unit Pelaksana Teknis Daerah) di Dishub Kabupaten Bandung Barat khususnya pada data analisis kendaraan data analisis pemohon dengan menggunakan kategori-kategori untuk membuat laporan dengan mengimplementasikan Dashboard Business Intellegence. Hasil penelitian ini adalah memberikan solusi alternatif bagi KA UPTD untuk lebih cepat tanggap terhadap kegiatan yang ada di Pengujian kendaraan serta mampu memberikan informasi, pengolahan data pengujian dan mengurangi timbulnya human error dalam pengujian kendaraan bermotor di Dishub Kabupaten Bandung Barat.
\end{abstract}

Kata kunci: business intellegence, KA UPTD, PKB.

\section{ABSTRACT}

PKB is a UPTD which tests motor vehicles that are based on the minister's regulation 1332015. When viewed from the Main Duty and Function (Tupoksi) position, the motor vehicle testers are the enforcement of the smoothness and suitability of vehicles Must be tailored to kepertoukannya. By testing all vehicle of goods transport and transportation of people UPTD Motor Vehicle Testing always protecting society to keep and maintain motor vehicle to remain functioned optimally for everyday use, UPTD PKB (Vehicle Testing) also one of important component in effort of improving economy and public safety, also as A progress indicator that has been achieved by a region. This study aims to build a motor vehicle test information system using Business Intllegence to facilitate employees and KA UPTD (Head of Regional Technical Implementation Unit) in Dishub Regency of West Bandung, especially on vehicle data analysis data of applicant analysis by using categories to create report by implementing Business Intellegence Dashboard. The result of this research is to provide alternative solution for UPTD KA to be more responsive to existing activities in vehicle test and able to provide information, data processing test and reduce human error in motor vehicle test in Dishub Regency of West Bandung.

Keywords: business intellegence, KA UPTD, PKB. 


\section{PENDAHULUAN}

Dinas Perhubungan merupakan unit pelaksana di bidang perhubungan yang dipimpin oleh seorang Kepala Dinas dan berada di bawah Sekretaris Daerah dan bertanggung jawab kepada Bupati, dalam tugasnya Dinas Perhubungan Kabupaten Bandung Barat memiliki beberapa peranan diantaranya menyelenggarakan urusan pemerintahan dan pelayanan umum bidang perhubungan Dinas Perhubungan Kabupaten Bandung Barat. Beberapa bidang yang terdapat di Dinas Perhubungan Kabupaten Bandung Barat salah satunya UPTD pengujian kendaraan bermotor, UPTD pengujian kendaraan bermotor merupakan bagian yang memiliki peran paling penting, yaitu dalam melakukan pengujian kelayakan jalan terhadap kendaraan angkutan darat. Di dalam proses pengujian itu sendiri memiliki tiga proses yaitu proses pendaftaran, proses pembayaran dan proses pengujian. Penyimpanan arsip dari berkas uji kendaraan yang tidak terstruktur karena tidak adanya pencatatan menyebabkan proses pencarian menjadi lambat. Selain arsip kepala UPTD sulit dalam menemukan atau mencari informasi pengujian kendaraan bermotor yang sering melakukan pengujian dan melihat hasil pengujian yang lulus uji atau gagal uji ketika gagal pengujian dilihat gagal pengujiannya di bagian mana sehingga kepala UPTD dapat menerima informasi dan analisis tentang pengujian kendaraan bermotor. Salah satu penerapan sistem yang dapat diaplikasikan untuk menunjang proses analisis yang dilakukan oleh Kepala UPTD dalam mendukung keputusan adalah Business Intelligence (BI), Business Intelligence merupakan sistem dan aplikasi yang berfungsi untuk mengubah data dalam suatu perusahaan atau organisasi (data operasional, data transaksional, atau data lainnya) ke dalam bentuk pengetahuan pada suatu organisasi [1]. Business Intelligence (BI) juga merupakan salah satu bentuk implementasi teknologi informasi yang digunakan untuk membantu kegiatan seperti mengumpulkan data, menyediakan akses, serta menganalisis data dan informasi mengenai kinerja perusahaan. Dengan kegiatan BI tersebut maka sebuah organisasi atau perusahaan akan dengan mudah dalam mengambil keputusan secara cepat dan tepat [2].

Penelitian ini bertujuan untuk membangun sistem yang dapat digunakan untuk mempermudah pengolahan data pengujian kendaraan bermotor dan laporan pengujian kendaraan bermotor dengan pengolahan data tersebut menjadi informasi untuk menganalisis kegiatan pengujian kendaraan bermotor Kepala UPTD Dishub Kabupaten Bandung Barat diberi judul "Pembangunan Perangkat Lunak Bisnis Intelegence di Dinas Perhubungan Kabupaten Bandung Barat”.

\section{METODOLOGI PENELITIAN}

Penelitian ini dilakukan secara sistematis, mulai dari pengidentifikasian masalah, pengumpulan data, menganilisis data, sampai menciptakan hasil yang baik, untuk membuat perangkat lunak bisnis intelligence yang baik, diperlukan data yang dibutuhkan melalui tahapan tahapan penelitian sebagai berikut:

\subsection{Identifikasi Kebutuhan}

Melakukan identifikasi proses bisnis yang sedang berjalan, mengidentifikasi langkah-langkah dalam mengambil keputusan untuk suatu kendaraan di anggap sebagai kendaraan yang sudah lulus uji, mengidentifikasi sistem informasi yang saat ini digunakan oleh UPTD Pengujian Kendaraan Bermotor Kab, Bandung Barat. Dan menganalisis data apa saja yang tersedia di UPTD Pengujian Kendaraan Bermotor Kab, Bandung Barat. Dengan data yang ada pada Sistem Informasi Pengujian Kendaraan Bermotor.

\subsection{Analisis dan Perancangan}

Menganalisis proses bisnis yang sedang berjalan, data apa saja yang berhubungan dengan permasalahannya untuk kemudian dirancang gambaran sistem yang akan dibuat. Berdasarkan identifikasi sebelumnya, Kepala UPTD Pengujian Kendaraan Bermotor Kabupaten Bandung Barat kesulitan dalam mendapatkan informasi yang diharapkan karena informasi yang ada saat ini masih berdasarkan hasil pengujian saja. Berikut data dari sistem yang ada di UPTD Pengujian Kendaraan Bermotor Kabupaten Bandung Barat.

\subsubsection{Data Pemohon}

Data yang berisi informasi yang akan melakukan pengujian kendaraan bermotor seperti nama, alamat rumah dll. 


\subsubsection{Data Pengujian Kendaraan Bermotor}

Data yang berisi tentang hasil pengujian kendaraan apakah sesuai dengan standar yang telah ditetapkan oleh UUD.

\subsection{Pembuatan Perangkat Lunak}

Pada tahap ini sistem mulai dibuat berdasarkan perancangan. Melakukan pengkodean dengan bahasa pemrograman PHP untuk merealisasikan desain yang dibuat menggunakan Object Oriented Programming (Use Case Digaram).

\subsection{Pengujian Perangkat Lunak}

Sistem sudah selesai dibuat. Pada tahap ini sistem yang dibuat akan diuji apakah sistemnya layak atau tidak untuk diimplementasikan. Contoh yang akan diuji seperti informasi yang dihasilkan apakah sudah akurat atau masih terdapat bug atau error sehingga meminimalisir kesalahan informasi yang di hasilkan.

\subsection{Implementasi}

Tahap ini adalah tahap dimana sistem sudah siap diterapkan atau sudah mulai siap digunakan oleh Kepala UPTD Pengujian Kendaraan Bermotor Kabupaten Bandung Barat sehingga tidak ada lagi kesalahan ketika sistem sudah diimplementasikan karena sebelumnya program sudah diuji terlebih dahulu.

\subsection{Laporan dan Evaluasi}

Membuat dokumentasi dari mulai awal penelitian sampai perangkat lunak sudah dibuat. Kemudian mengevaluasi secara keseluruhan dari awal sistem dirancang hingga diimplementasikan secara nyata.

\section{HASIL DAN PEMBAHASAN}

Hasil dan pembahasan merupakan penjelasan atau gambaran dari perangkat lunak yang dibangun, terdapat beberapa komponen yang ada dalam Business Intellegence, diantaranya yaitu sumber data, staging area dimana komponen ini merupakan proses ekstraksi data melalui proses ETL. Kemudian komponen data warehouse selanjutnya data yang tersimpan dalam data warehouse akan dianalisis dan akan menampilkan informasi dari hasil analisis data tersebut, berikut arsitektur Business Intelligence dapat dilihat pada Gambar 1.

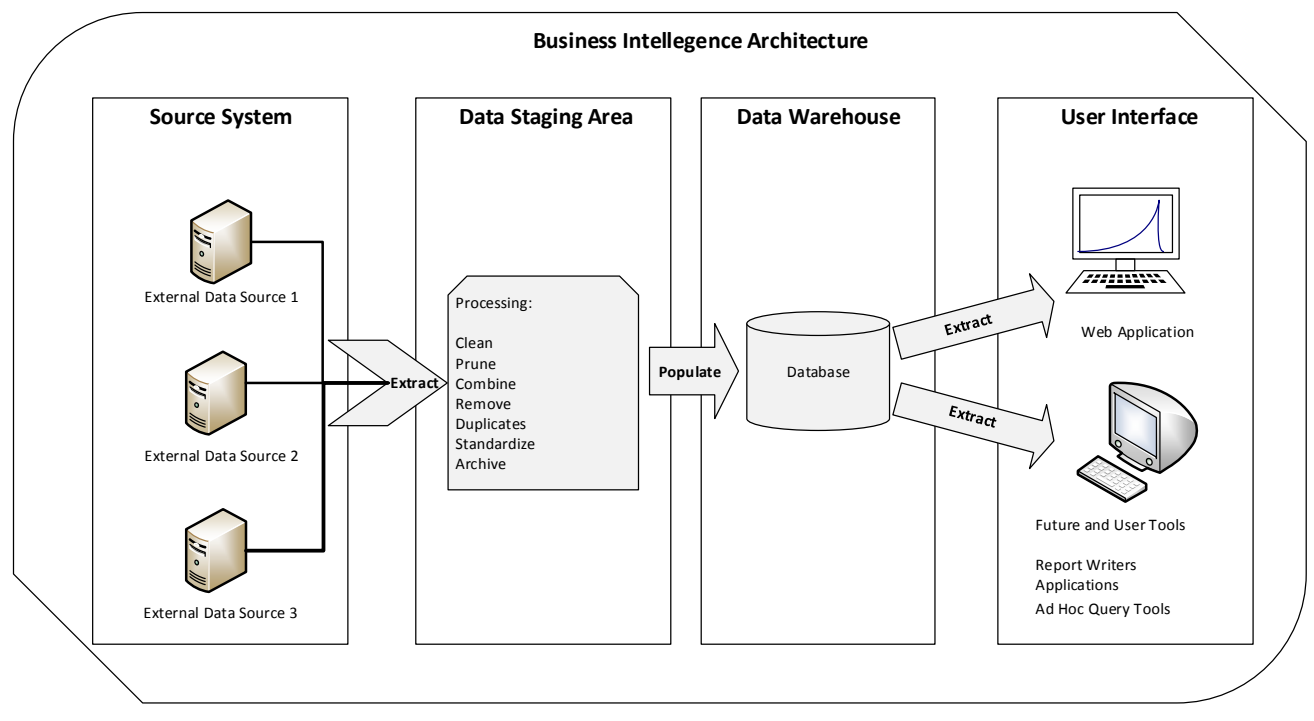

Gambar 1. Arsitektur Business Intellegence[3] 


\subsection{Data Warehouse}

Terdapat 12 tabel yang terkait dalam perancangan data warehouse ini yaitu database Pengujian Kendaraan Bermotor. Dalam merancang data warehouse terdapat 3 tahapan.

\subsubsection{Input}

Masukan yang akan di proses di dalam perangkat lunak ini yaitu berupa data pendaftaran pemohon, data pembayaran, dan data pengujian dalam bentuk excel $(x l s)$, data tersebut yang nantinya akan dimasukan ke dalam database.

\subsubsection{Process}

Terdapat proses Extract, Transformation dan Loading. Proses Extract adalah proses penyaringan data dari data sumber, atau pemilihan data yang dibutuhkan dari data sumber untuk dimasukkan ke dalam Data Warehouse. Proses Transformation adalah menjalankan serangkaian perintah dan fungsi dari data yang telah di-extract untuk mendapatkan data yang sesuai yang akan di loading ke dalam Data Mart. Seperti pembersihan data, standarisasi elemen data, melakukan translasi kode, menghasilkan nilai perhitungan yang baru, melakukan proses join dari sumber yang berbeda, misalnya pada proses lookup atau merge, dan lain-lain. Dan terakhir proses Loading adalah tahap terakhir ini akan mengisi data ke dalam data warehouse.

\subsubsection{Output}

Proses ini adalah proses untuk menyajikan data yang sudah tersedia pada kubus multidimensi. Proses ini dilakukan dengan menentukan kriteria query berdasarkan kebutuhan pengguna dalam menganalisis data. Sistem akan melakukan pengambilan data dalam basis data dan menyajikannya ke dalam bentuk grafik yang mudah dipahami.

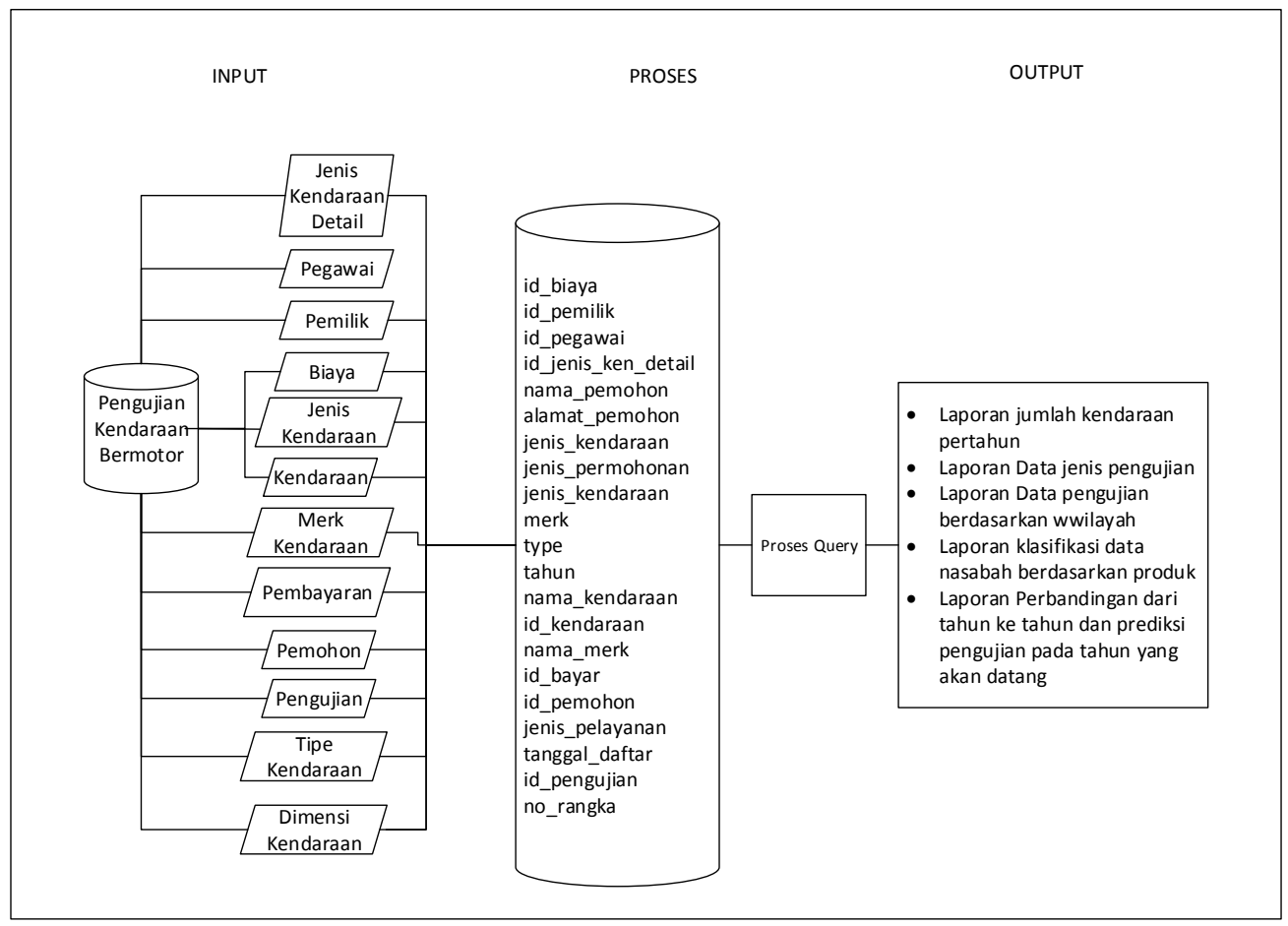

Gambar 2. Gambaran Umum Perancangan Data Warehouse[4]

\subsection{Proses Denormalisasi Database Pengujian Kendaraan Bermotor}

Proses denormalisasi database pengujian kendaraan bermotor dimana database pengujian kendaraan bermotor memiliki 11 tabel yaitu tabel biaya, tabel pemilik, tabel pegawai, tabel jenis kendaraan, jenis 
kendaraan detail, tabel kendaraan, tabel merk kendaraan, tabel pembayaran, tabel pemohon, tabel pengujian dan tabel type kendaraan. Proses ini dapat dilihat pada Gambar 3 Denormalisasi Database Pengujian Kendaraan Bermotor.

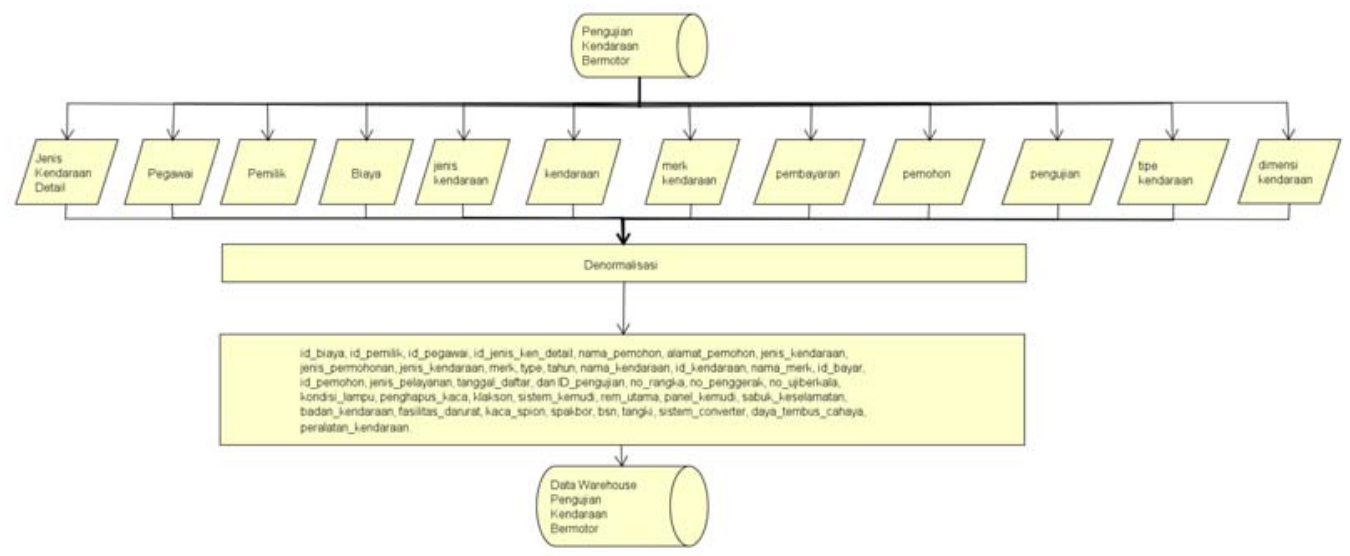

Gambar 3. Denormalisasi Database Pengujian Kendaraan Bermotor

\subsection{Implementasi}

\subsection{1 Меnu Utama}

Menu utama merupakan halaman awal yang ditampilkan oleh sistem ketika pengguna berhasil login, berikut halaman menu utama dapat dilihat pada Gambar 4.

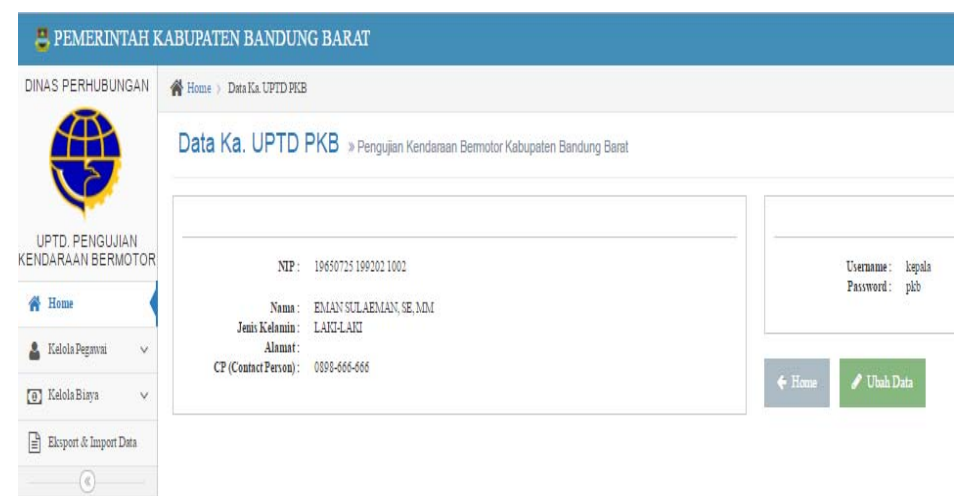

\section{Gambar 4. Menu Utama}

\subsubsection{Data Pendaftaran Uji Berkala}

Data pendaftaran uji berkala adalah halaman data pemohon yang akan melakukan pengujian kendaraan bermotor dapat dilihat pada Gambar 5 . 


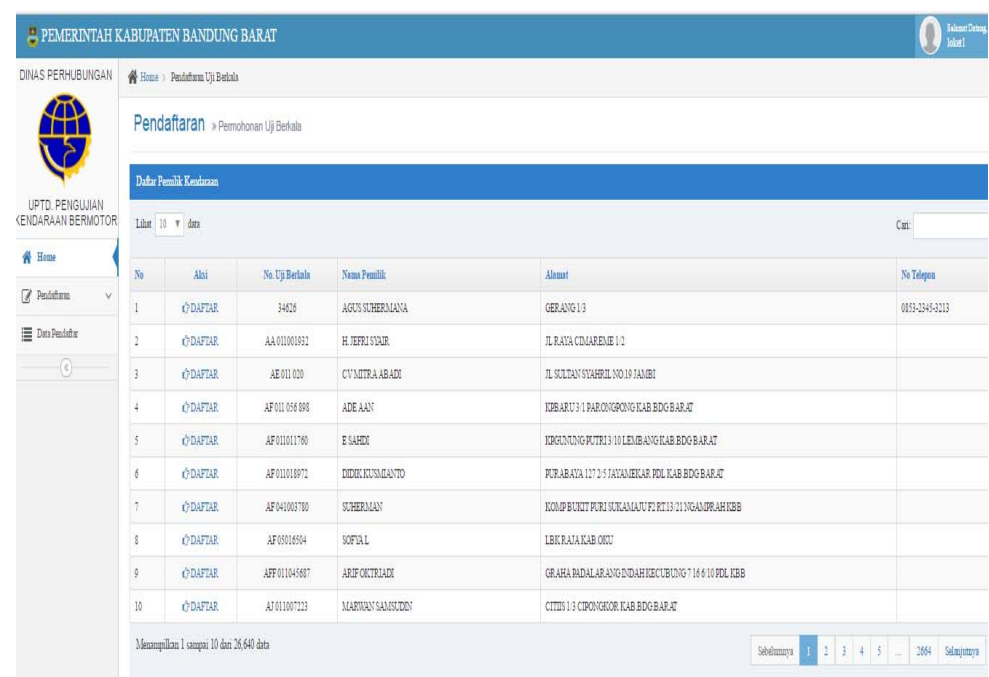

\section{Gambar 5. Data Pendaftaran Uji Berkala Loket 1}

\subsubsection{Data Pengujian Penguji}

Data Pengujian penguji adalah proses pengujian yang dilakukan oleh penguji yang ada 3 tahapan seperti di bawah ini pada gambar 6 .

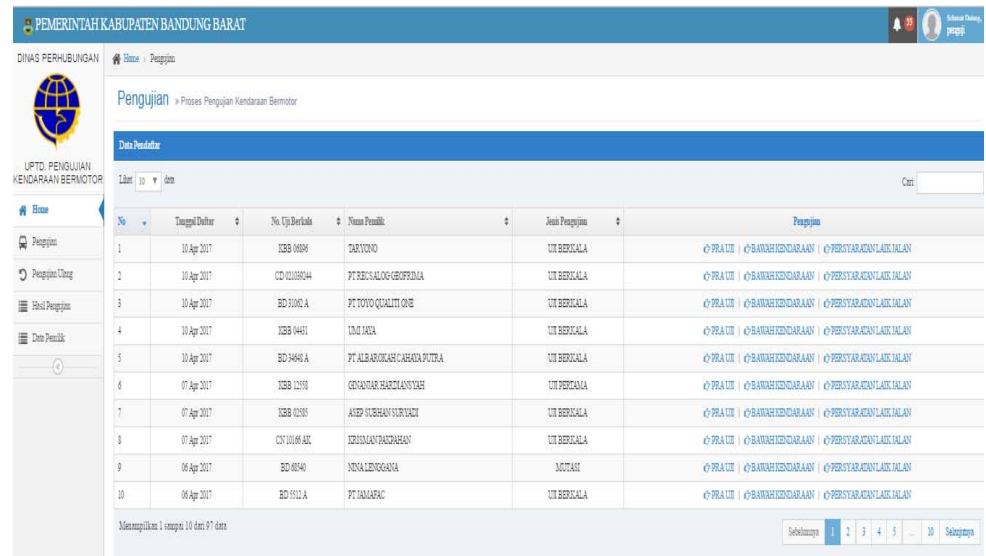

\section{Gambar 6. Implementasi Pengujian}

\subsubsection{Data Hasil Pengujian Penguji}

Data hasil pengujian penguji adalah hasil pengujian yang menunjukan lulus atau tidak kendaraan yang sudah di uji dengan data pemilik atau pemohon dapat dilihat pada Gambar 7. 


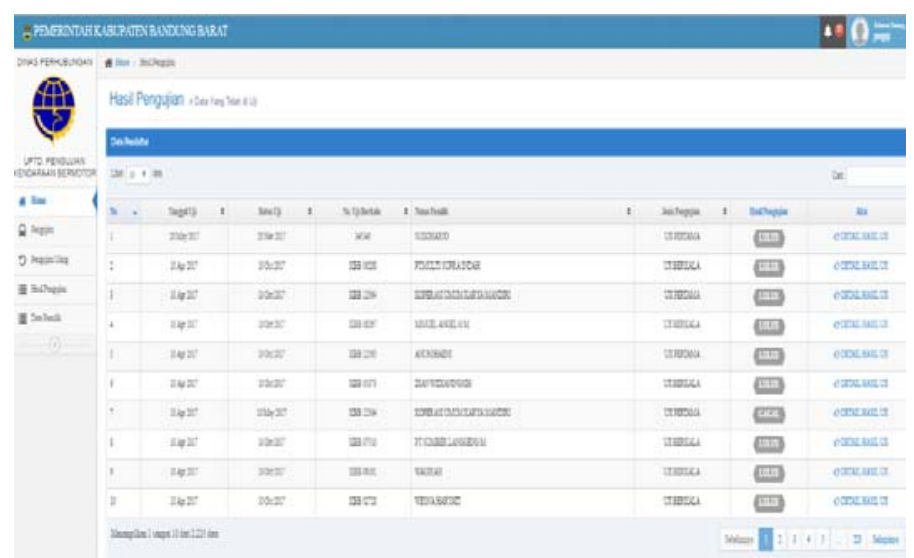

Gambar 7. Data Hasil Pengujian Penguji

\subsubsection{Laporan Grafik Hasil Pengujian}

Laporan grafik hasil pengujian adalah laporan grafik batang berdasarkan jumlah pengujian dari tahun ketahun dapat dilihat pada Gambar 8.

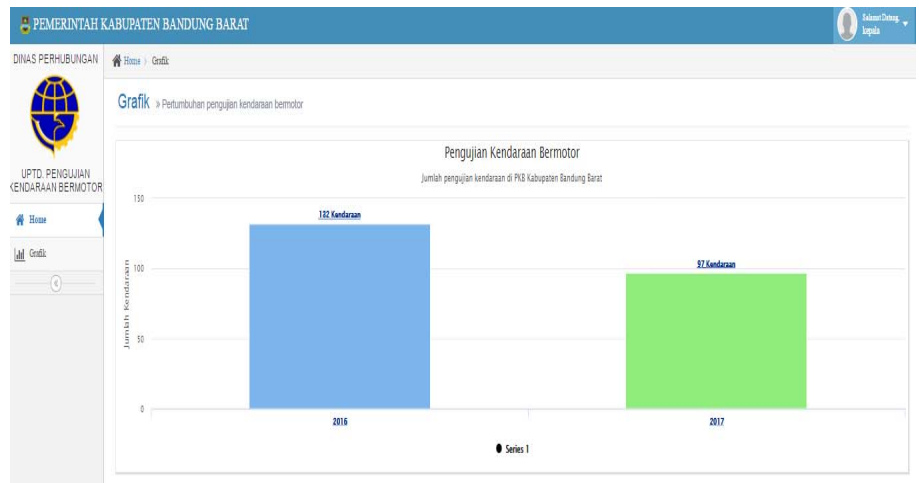

\section{Gambar 8. Laporan Grafik Hasil Pengujian}

\subsubsection{Tampil Grafik Kepala Menurut Wilayah}

Tampil Grafik Kepala Menurut Wilayah adalah menerangkan tentang pengujian kendaraan berdasarkan wilayh. Bisa di tampilkan semua wilayah atau berdsarkan wilayah tertentu bisa di pilih wilayah-wilayahnya.

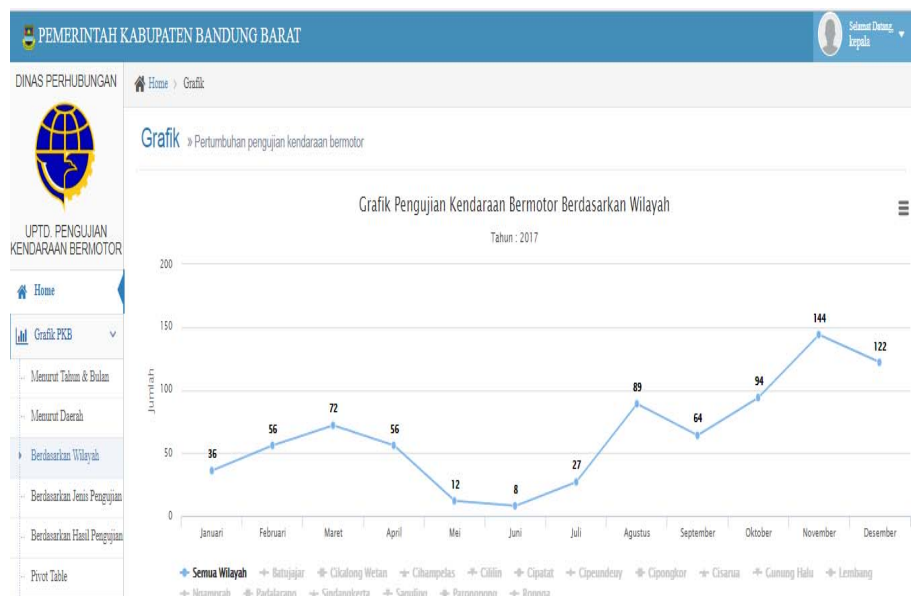

Gambar 9. Laporan Grafik Hasil Pengujian 


\section{KESIMPULAN}

Berdasarkan hasil dari penelitian yang dilakukan, dapat disimpulkan dengan adanya Perangkat lunak Business Intelligence pada Dinas Perhubungan Kabupaten Bandung Barat bagian Pengujian Kendaraan Bermotor ini dapat membantu pihak manajemen dalam memperoleh informasi secara cepat dan rinci. Berdasarkan dari analisis sistem berjalan serta analisis fungsionalitas yang telah dilakukan sebelumnya, perangkat lunak ini dibuat sehingga dapat memberikan fitur import data dan melihat informasi sesuai dengan kebutuhan. Import data merupakan proses memasukan data ke dalam datawarehouse melalui proses ekstract data kemudian data tersebut disimpan ke dalam database untuk dijadikan sumber data yang akan menampilkan informasi pengujian kendaraan bermotor berdasarkan tahun dan bulan, berdasarkan wilayah dan daerah berdasarkan jenis pengujian dan berdasarkan hasil pengujian

\section{DAFTAR PUSTAKA}

[1] Saluky, "Aplikasi Business Intelligence Menggunakan Metode Balanced Scorecard untuk Mengukur Kinerja Marketing Indosat Cirebon," Jurnal Informatika, vol. 7, pp. 191-200, 2011.

[2] M. Arifin, "Business Intelligence untuk Prediksi Customer Churn Telekomunikasi," in SNATIF, Kudus, 2014.

[3] M. Aris, S. Ferry, R. Deden and R. Nina, "Rancang-Bangun Business Intelligence Pada Perpustakaan Sekolah SMP Negeri 1 Cisoka," Seminar Nasional Teknologi Informasi dan Multimedia 2013, no. 2302-3805, pp. 18-38, 2013.

[4] F. Vahid and P. Lászl, "The necessities for building a model to evaluate Business Intelligence projects- Literature Review," International Journal of Computer Science \& Engineering Survey (IJCSES), vol. 3, no. 10.5121/ijcses.2012.3201, pp. 1-10, 2012.

[5] Maimunah, F. S. Siti and A. Randy, "Rancang Bangun Aplikasi Data Warehouse Untuk Business Intelligence," CSRID Jurnal, vol. 4, pp. 27 - 36, 2012.

[6] R. Hashemi, K. Nia and H. Khodijah, "Pengembangan Aplikasi Business Intelligence Untuk Bagian Operasional Dan Keuangan Pada Perusahaan Gerbang Multindo Nusantara," Jurnal Sistem Informasi, vol. VI, no. ISSN 1979-0767, pp. 1-16, 2013.

[7] D. P. Susan and N. K. Yesi, "Dashboard Business Intelligence Sebagai Penunjang Keputusan Menentukan Jumlah Kelas," JURNAL ILMIAH MATRIK, vol. 16, no. ISSN : 1411-1624, pp. 1-20, 2014.

[8] P. A. Stephanie, W. Irya and L. S. Benyamin, "Analisis dan Desain Real-Time Business Intelligence Untuk Subjek Kegiatan Akademik pada Universitas Menggunakan Change Data Capture," Seminar Nasional Teknologi Informasi dan Komunikasi 2013 (SENTIKA 2013), no. ISSN: 2089-9815, pp. 88-95, 2013.

[9] Suyoto and G. L. Tri, "Peningkatan Penjualan Bahan Bangunan Melalui Penerapan Bisnis Intelligence Menggunakan Metode OLAP ( Online Analytical Process)," Jurnal Online ICT STMIK IKMI Cirebon, no. ISSN : 2302-0261, pp. 1-8, 2013.

[10] Husni, N. Zaky, Mukhlash and Imam, "Implementasi Business Intelligence Pada Manajemen Report Bank XYZ," JURNAL SAINS DAN SENNI POMITS, vol. III, no. ISSN: 2337-3539, pp. A-16-A-21, 2014. 